\title{
A Competitive Success Model in the Hotel Industry
}

\author{
Completed Research Paper
}

\author{
M.Rosario González-Rodríguez \\ University of Seville \\ rosaglez@us.es
}

\author{
Rosario Martín-Samper \\ University of Seville \\ rmartin@us.es
}

\author{
José Luis Jiménez-Caballero \\ University of Seville \\ jjimenez@us.es
}

\begin{abstract}
The aim of the paper focus on identifying those factors involved in the competitive success of hotel companies and the interrelations between them, taking into account the socio-economic influence that these companies might have on Andalusian region and the few studies carried out in tourism sector so far. The study tries to specify an econometric model that may include factors that appear as mechanisms for the generation of competitive advantage. The research model allows us to identify the relative impact of the "industry factor" and the company's own specific factors, "hotel intangible resources", on competitive success.
\end{abstract}

Keywords: competitiveness, firm assets, industry forces, strategy management, profitability, market position.

\section{Introduction}

The relevance of the Tourist Industry in Spanish economy is a good reason to carry out a research related to this Sector. Economic indicators support this statement. The weight of the Tourist Sector in GDP is similar to that of the Building Industry or the Industrial Sector, reaching $11 \%$ of GDP in 2011 (three times the Primary Sector) and offering employment to over 2,3 million people in our country . The figures from Andalusia are even more significant reaching $12,5 \%$ of GDP, $13 \%$ the total employment and $8 \%$ of the investment in this Region (INE, 2011).

Hotel companies, one of the pillars in the tourist industry, recently experienced a profit making period. Nevertheless, they were also affected by the current crisis, reaching smaller growth rates than those of previous years and experiencing an important profit reduction. (CHEAT and Pricewaterhouse Coopers 2008).

In the last decades, the sector's growth demanded deep changes which emerged in the eighties, whose main purposes were to improve competitiveness, sustainability and quality in tourist companies. Cost management and the generation of value have appeared as basic pillars of the changing process. The tourist sector should easily adjust to market changes by offering innovative products that may meet the client's needs together with better quality and price levels as expected by their market niche.

In today's society, characterized by a global and dynamic economy in an age of important technological change and strong competition, the tourist sector's challenge is to develop new 
capabilities, new modern, appropriate management systems adjusted to the new scenarios in order to achieve competitive advantages and therefore better results..

\section{Literature Review and Research Hypotheses.}

In order to identify and analyze the success factors and their interrelations which improve the competitiveness in hotels, we focus on the Resource and Capability Theory which was developed and used by many researches from the sixties to the present (Penrose, 1959; Barney, 1991; Grant, 1991; Amit and Schoemaker, 1993; Fernández, 1993; Nightwear, 1996; Dales and Guerra, 1996; Monfort, 2000; Ballast et to the, 2003; I Prick with Thorns and Census 2005).

That theory considers the company an idiosyncratic group of resources and capabilities with imperfect mobility. Each company's heterogeneous nature may be sustained over a long term since as Barney (1991) states those resources are characterized to be heterogeneous, rare, valuable, durable, inimitable, inappropriate and irreplaceable.

Many authors tried to identify those success and competitive factors peculiar to companies. Wernerfelt (1984) and Grant (1991, p.19) established a first classification for these factors into two groups, external and internal. External factors are those which cannot be controlled by a company and arise from the very environment performance of the company such as the social, economic, political and legal variables. External factors include a group of characteristics that make up the industrial environment under which competition is developed among companies, and is known as "industry factor". Although tourist companies are especially sensitive to external variables, capabilities and resources are used by the companies to defend themselves from an unfavorable environment and to take advantage of the potentialities that this situation involves.

Internal factors are those variables peculiar to each company and thus controllable by them. They make companies different from one another. Resources can be classified into tangible and intangible factors. On one hand, tangible factors include both physical resources (facilities, properties, machinery, etc.) and financial resources which allow a company to undertake the necessary investments for its purposes. On the other hand, intangible resources include capabilities developed by company members and human, technological, reputational and organizational resources.

Although those researches were first, based on the resource and capability theory, and focused on the internal factors, in the last two decades studies tended to identify internal factors as being responsible for competitive success. In hotel companies, due to their own characteristics which distinguish them from each other, the development of abilities and capabilities as well as the rest of intangible resources is really outstanding.

Since intangible resources especially in the tourist sector are also important for any company, a conceptual and methodological framework to analyze how and in what way such resources may influence the competitive success is necessary. Nevertheless, we focused not only on intangible factors, but also on other factors which may affect competitiveness such as strategy selection and these very specific factors of the hotel industry (industry effect). In fact, recent literature recognized that theories based on "competitive strategy" and on "resources and capabilities" complemented each other and were capable to explain a company competitive success (Amit and Schoemaker 1993; Mahoney 1995). According to Wernerfelt (1984), Porter's conceptual framework and the resource and capability theory are two sides of the same coin.

The current research relies on an econometric model that may reconcile theories based on "competitive strategy" and "resources and capabilities" (Figure 1). The specification of the 
model may be justified according to the following issues: a) the two theories are complementary and explanatory of the competitive success, in the sense that one may obtain a more balanced viewed of competitive advantages; $b$ ) both perspectives try to explain the same phenomenon (sustainable competitive advantage); and c) the unit of analysis is the same in both theories, "company".

The variables included in the model are, "competitive success" as an explained variable, and "intangible resources", "strategy position" and "industry effect industry" as explanatory variables. The variable hotel size (number of rooms) is included as a control variable in order to remove the effect of this variable on dependent variable.

The main objective of the specified model is to show the relative impact of the "industry factor" and specific factors of the company "intangible hotel resources" on competitive success. The study tries to identify the pattern of those factors which may explain hotel sector's success as causal mechanisms for the generation of competitive advantage.

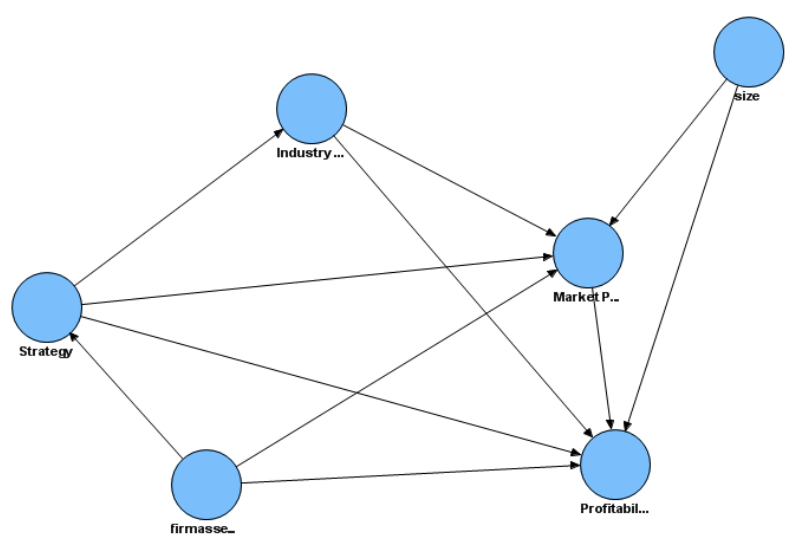

Figure 1: Research Model for Competitive success

This multidirectional model incorporates the following effects: i) "Strategy Effect" that is a necessary condition to achieve competitive success; ii) "Industry Effect" and iii) "peculiar effects" (indirect effects) of the those variables that would provide enough conditions for sustainability of the competitive advantage.

According to the approach described above the following hypotheses could be formulated:

H1: Competitive success depends directly and indirectly on the intangible resources;

H2: Competitive success depends directly and indirectly on the variable "industry effect"

H3: competitive success" depends directly and indirectly on the variable "strategy.

The nature of this research requires the development of a structured survey addressed to the hotel manager. The survey uses subjective measures which allow the study to define the latent variables considered in the model. All the constructs are measured using Liker scales. Given the peculiarities of the hotel company, most of the used scales were adapted from scales widely validated in the extensive literature on the relevant factors of competitive success. The questionnaire is structured in five parts: the first one is designed to gather data related to the company and the director's profile, the four remaining parts collected questions that measure "competitive success", "intangible resources", "strategy position" of the company and the "industry effect".

\section{Methodology}

\subsection{Sample and data collection}


The study focuses on individual firms from the hotel sector to analyse the effects of the strategy, resources and capabilities and industry forces on their strength on competitiveness in the tourist destination area where they operate. In the present study, we choose to employ a survey-based method to collect data and detect any possible relationship between variables, particularly for those which are unobservable constructs mentioned before as strategy, resources and capabilities and industry forces. Different stages were followed to ensure response quality and high response rate. First, a questionnaire was designed according to theoretical contributions on those topics. Validated scales from the literature review to measure those constructs were used in the questionnaire. Second, due to the particularity of the tourism sector, the research instrument was adapted to the sector and pretested by interviewing CEOs from hotels with three, four and fifth stars. Third, according to CEOs recommendations and discussions with questionnaire design experts the initial questionnaire was modified to launch.

The final questionnaire was based on multi-item seven-point likert scales questions for those aspects related to firm assets, management strategy, and competitive environment. The survey also included control variables to remove any effects they might have on firm performance as size (number of employees, capacity in terms of available rooms). Other variables related to firm as age, operating regime (ownership, management, rental, franchise, other), typology (chain, family business), and variables related to the CEO as gender and years of experience were include.

To determine the sample size, the recommendation by Green (1991) with a statistical power of $80 \%$ was followed. Considering the four predictor variables for the latent dependent variable, an initial minimum sample size of 124 hotels was needed to capture large predictor variables effects, 59 hotels for medium effects and 38 for small effects to obtain a statistical power of 0.80 and an alpha level of 0.05 . CEOs were interviewed by telephone to obtain the highest quality response and highest response rate. The non-response rate was $6 \%$ and final sample with 94 hotels operating in the province of Seville (andalusian region) were used for the analysis.

Table 1 shows the main descriptive statistics for the research variables.

\begin{tabular}{|lllllllllllllll|}
\hline Typology & \multicolumn{4}{c}{ Operating Regime } & \multicolumn{4}{c|}{ Chain } & \multicolumn{4}{c|}{ Classific stars } \\
\hline Urban & Vacational & Prop & Manag & Rental & Franch & Other & Yes & No & 2 & 3 & 4 & 5 \\
$66.3 \%$ & $33.7 \%$ & $30.4 \%$ & $19.6 \%$ & $41 . \%$ & $6.5 \%$ & $2.2 \%$ & $69.6 \%$ & 30.4 & 9.8 & 25 & 55 & 9.8 \\
\hline
\end{tabular}

Prop: Property; Manag: Management; Franch: Franchise.

\begin{tabular}{|lcccccccccc|}
\hline Family group & CEO gender & \multicolumn{3}{c|}{ CEO age } & \multicolumn{2}{c|}{ CEO experie (years) } \\
\hline Yes & No & Man & Woman & 1 & 2 & 3 & 4 & Min & Max \\
$50 \%$ & $48.9 \%$ & $68 \%$ & $26.1 \%$ & 0 & $28.3 \%$ & $55.4 \%$ & $16.3 \%$ & 2 & 37 \\
\hline
\end{tabular}

1.- Lower than $25 ; 2: 26-35 ; 3: 36-50$; over 50

\subsection{Measurement of latent variables}


As described above a multi-item 7-point Likert scales were used to measure the industry forces, strategy and firm performance. Measures widely applied in the industrial sector were adapted to the hotel sector.

The firm performance was treated as a two-dimension construct, profitability and market performance. While Profitability represent as the internal-based performance dimension, market share appears to be the external-based performance dimension (Spanos and Lioukas, 2001).

The two dimensions were measured by the question, "please indicate for each following item the position of your firm relative to competition for the last three years $(1=$ much below the average to $7=$ much above the average). Profitability was measured by different indicators as Profit margin, return on own, Net profit. Cronbach's alpha for profitability was 0.984 . Market performance Market position was measured by Sales volume, Growth in sales volume, Market share, Growth in market share. Crobach's alpha for Market position was 0.980 .

These two performance measures were chosen since they have been most widely used in the literature as two dimensions of firm performance (Venkatraman and Ramanujam, 1986; Davis et al., 200; Spanos and Lioukas, 2001).

The internal-based performance and external-based performance were included in the model as two lower order constructs (and therefore not being included in a higher order construct) since Market performance appear in most empirical studies as influencing positively and significantly firm profitability (Chang and Buzzell, 1983; Prescott et al., 1986; Galbreath and Galvin, 2006).

The measurement of the industry forces tries to capture the five Porter's (1980) competitive forces by which managers can create and sustain competitive advantage will give a company above-average profitability. Barriers to entry, threat of substitutes, bargaining power of buyers, bargaining power of suppliers were measured by single item questions and current rivalry.

The first four industry forces were measured by single item questions (Spanos and Lioukas, 2001; Galbreath and Galvin, 2006): "Please, provide the more accurate answer for each following item": Number of hotel competing directly with his/her hotel (1: very high to $7=$ very low $)$; Is it easy the entry of competitive hotel in his/her sector? $(1=$ very easy to enter to $1=$ very difficult to enter); Is your sector threat by substitutes? $(1=$ not at all to $7=$ very extreme); what is the bargaining power over your customers? $(1=$ very weak to $7=$ very strong); What is the bargaining power over your suppliers? ( $1=$ very weak to $7=$ very strong).

The competitive rivalry was a composite construct (Achrol and Stern, 1988) measured by CEOs answer to the following question: How would you evaluate the intensity of competition your firm is facing with respect to ( $1=$ very week competition to $7=$ very strong competition): service strategies characteristics; product characteristics; physical hotel characteristics; promotional strategies; access to distribution channels. The Cronbach's alpha for rivalry was 0.786 .

Once managers have determined what threats and opportunities exist in the environment they operate, the appropriate competitive strategy should be selected. The scale derived and adapted to the hotel sector from Miller (19988), consisted of asking to the extant of usage competitive strategies ( $1=$ much less than competitors to $7=$ much more than competitors) related to marketing differentiation, innovation differentiation strategy. The strategy appears in the model as formative construct since firms can followed different strategies to seek a competitive advantage.

The firm assets was defined as a higher order construct including the organizational, marketing, technical and reputational capabilities as dimensions following empirical studies 
as Monfort (2000), Spanos and Lioukas (2001) and Galbreath and Galvin (2006).

To measure each dimension CEOs were asked to respond the following question: "Please, indicate for each of the following resources, the firm strength to your competition ( $1=$ much weaker than competitors to $7=$ much stronger than competitors).

Organizational assets included managerial competencies, culture climate, strategic planning, efficient organizational structure, coordination in hotel hierarchy, skills and knowhow of the hotel employees, ability to attract creative employees. Cronbach's alpha 0.947

Marketing capabilities consisted of four items as market knowledge, control and access to distribution channels, advantageous relationship with customers and suppliers, customer installed based. Cronbach's alpha 0.910.

Technical capabilities defined by technological resources (central reserve system, intranet, e-booking), hotel equipment and geographical localization. Cronbach's alpha 0.912.

Reputational assets including customer service reputation and company reputation related to social and environmental responsibility. Cronbach's alpha 0.952 .

Control variables.

Strategy

Firm size (number of employees) constitutes a common control variable to be used to remove whatever effects it could have on firm performance.

\section{Results}

The structural relations among the constructs proposed in our research model were tested applying Partial Least Squares (PLS), a variance-based structural modeling technique. PLS constitutes family of least squares algorithm, which applies principal component and canonical correlation analyisis (Henseler et al., 2009). PLS modeling technique presents certain advantages for researchers and practitioners in social sciences (Hair et al., 2014). First, the method focuses on prediction of a set of hypothesized relationships maximizing the explained variance of the dependent variable. Second, PLS path models can be very complex involving many latent and manifest variables without leading to estimation problems (Wold, 1985). Third, PLS presents a greater flexibility regarding to sample size and normal data distribution requirement than the covariance-based SEMs. PLS-SEM provides very robust model estimations with either normal distribution data or non-normal distribution data (Ringle et al., 2009).

\subsection{Measurement Model}

The construct firm assets has been defined as a reflective-formative second-high order construct (HOC) from constructs such as marketing, organizational, technical and reputational capabilities. Strategy has been defined as a formative-formative HOC from marketing differentiation, Innovative differentiation and low cost strategy. For both constructs, a secondStage Approach for hierarchical component models (HCM) (Ringle et al., 2012) has been applied. The measurement model evaluation for reflective constructs was based on the construct internal consistency (composite reliability), convergent (item reliability and AVE, the average variance extracted), discriminant validity by Fornell-Lacker criterion (Hair et al., 2014, Henseler et al., 2009) and Heterotrait-monotrait ratio of correlations (HTMT) (Henseler et al., 2015).

\subsection{Validity Assesment of Reflective Measurement Models}


Form Table 1 all reflective constructs present internal consistency reliability with composite reliability measures greater than 0.9 . All reflective construct show convergent validity with factor loading greater than 0.707 , and AVE measures higher than 0 . For adequate discriminant validity, the diagonal elements should be exceeding the square correlations with any other constructs (Barclay et al., 1995). This requisite is satisfied for the latent reflective variables of the research model.

Table 1: Measurement Model Reflective Constructs

\begin{tabular}{|c|c|c|c|c|}
\hline Constructs & Items & $\begin{array}{l}\text { Composite } \\
\text { reliability }\end{array}$ & $\begin{array}{l}\text { Item } \\
\text { reliability }\end{array}$ & AVE \\
\hline Competitive rivalry & $\begin{array}{l}\text { Physical characteristics } \\
\text { Service Characteristics } \\
\text { Promotional strategies } \\
\text { Access to distribution } \\
\text { channels } \\
\text { Geographical Localization }\end{array}$ & 0.8635 & $\begin{array}{l}0.712 \\
0.843 \\
0.783 \\
0.728 \\
\\
0.664\end{array}$ & 0.5603 \\
\hline $\begin{array}{l}\text { Market } \\
\text { Performance }\end{array}$ & $\begin{array}{l}\text { Sales volume } \\
\text { Sales growth } \\
\text { Market share } \\
\text { Growth Market share }\end{array}$ & 0.9843 & $\begin{array}{l}0.967 \\
0.983 \\
0.978 \\
0 .\end{array}$ & 0.9126 \\
\hline Profitability & $\begin{array}{l}\text { Profit margin } \\
\text { Return on capital } \\
\text { Net profit }\end{array}$ & 0.9885 & $\begin{array}{l}0.967 \\
0.983 \\
0.978\end{array}$ & 0.9554 \\
\hline $\begin{array}{l}\text { Marketing } \\
\text { Capabilities }\end{array}$ & $\begin{array}{l}\text { Market Knowledge } \\
\text { Control and access to } \\
\text { distribution channels } \\
\text { Advantageous relationships } \\
\text { with customers } \\
\text { Customer installed base }\end{array}$ & 0.9245 & $\begin{array}{l}0.827 \\
0.918 \\
\\
0.933 \\
0.799\end{array}$ & 0.7546 \\
\hline $\begin{array}{l}\text { Technical } \\
\text { Capabilities }\end{array}$ & $\begin{array}{l}\text { Technical resources } \\
\text { Hotel equipment }\end{array}$ & 0.856 & $\begin{array}{l}0.883 \\
0.847\end{array}$ & 0.748 \\
\hline $\begin{array}{l}\text { Organizational } \\
\text { capabilities }\end{array}$ & $\begin{array}{l}\text { Ability to attract creative } \\
\text { employees } \\
\text { Cultural climate } \\
\text { Organizational } \\
\text { Strategic planning } \\
\text { Efficient organizational } \\
\text { structure } \\
\text { Coordination } \\
\text { Skills and Know-how } \\
\text { employees }\end{array}$ & 0.9714 & $\begin{array}{l}0.782 \\
\\
0.887 \\
0.902 \\
0.918 \\
0.910 \\
\\
0.950 \\
0.925\end{array}$ & 0.810 \\
\hline $\begin{array}{l}\text { Reputational } \\
\text { capabilities }\end{array}$ & Environmental CSR & 0.928 & 0.867 & 0.6918 \\
\hline
\end{tabular}




\begin{tabular}{|ll|}
\hline Promote women on boards & 0.872 \\
Improve the socioeconomic & 0.840 \\
situation in the area it & \\
operates & \\
To improve vulnerable & 0.834 \\
groups' social integration & \\
\hline
\end{tabular}

Table 2: Measurement Model. Discriminant and HTMT Validity

\begin{tabular}{|c|c|c|c|c|c|}
\hline \multicolumn{4}{|c|}{ Discriminant validity Fornell-Larcker } & \multicolumn{2}{|c|}{ HTMT validity } \\
\hline & 1 & 2 & 3 & 1 & 2 \\
\hline 1. Rivalry Competitive & 0.750 & & & & \\
\hline 2. Market Performance & 0.566 & 0.955 & & $\begin{array}{l}0.627 \\
\text { C.I. }(0.541,0.703)\end{array}$ & \\
\hline 3. Profitability & 0.606 & 0.901 & 0.977 & $\begin{array}{l}0.674 \\
\text { C.I. }(0.601,0.748)\end{array}$ & $\begin{array}{l}0.90 \\
\text { C.I. }(0.886,0.945)\end{array}$ \\
\hline
\end{tabular}

Notes: Diagonal elements are AVE-Squared. Off-diagonal elements are correlations among constructs

Using HTMT as a criterion for validity, HTMT values close to 1 indicate lack of discriminant validity (Henseler et al., 2015), as seen from HTMT between the constructs profitability and market performance since both represent firm performance and could be reduced to a second HOC. However, we have decided to keep both constructs since the confidence intervals of the HTMT by applying boostraping procedure in order to test the hypothesis $\left(\mathrm{H}_{0}: \mathrm{HTMT} \geq 1\right)$, do not contain value one indicating discriminant validity.

\subsection{Validity Assesment of Reflective Measurement Models}

No critical levels of collinearity were observed in the formative construct Strategy (VIF lower than 5).

Table 3: Formative Construct

\begin{tabular}{|cccc|}
\hline Strategy & $\begin{array}{c}\text { Weights/ } \\
\text { outer loading }\end{array}$ & t & Sig. \\
\hline $\begin{array}{c}\text { Marketing Diferentiation: Innovation in Marketing } \\
\text { techniques } \\
\text { Innovative Diferiantiation: Innovation in process and } \\
\text { products }\end{array}$ & $0.259(0.752)$ & 2.01 & $* *$ \\
& $0.556(0.953)$ & 32.65 & $* * *$ \\
\hline Firm assets & Weights/ & t & Sig. \\
\hline Organizational & outer loading & & \\
Marketing & $0.144(0.752)$ & 2.01 & $* *$ \\
Technical & $0.156(0.953)$ & 3.65 & $* * *$ \\
& $0.235(0.872)$ & 2.65 & $* *$ \\
\hline
\end{tabular}

\subsection{Structural Model}

The Model to be estimated is composed of reflective and formative constructs, thus, traditional PLS algorithm instead of PLS consistent has been applied to estimate path relations (Dijkstra and Henseler, 2015). Results obtained from the estimated model in Figure 1 are shown in Table 4 and 5. Table 4 describes the direct effects observed of strategy, industry forces and firms assets on firm performance (profitability and Market performance) and Market performance on profitability. Table 5 presents the mediating effects of the strategy for the firm assets and competitive rivalry on firm performance. 
Table 4: Direct Effects on Firm competitiveness

\begin{tabular}{|c|c|c|c|c|}
\hline & \multicolumn{2}{|c|}{$\begin{array}{l}\text { Firm Performance } \\
\text { Path coefficients }\end{array}$} & \multirow[b]{2}{*}{$\begin{array}{l}\text { Strategy } \\
\mathrm{R}^{2}=0.266\end{array}$} & \multirow[b]{2}{*}{$\begin{array}{c}\text { Industry Forces } \\
\mathrm{R}^{2}=\mathbf{0 . 5 2 3} \text { (rivalry) }\end{array}$} \\
\hline & $\begin{array}{c}\text { Market } \\
\text { Performance } \\
\mathbf{R}^{2}=0.535 \\
\end{array}$ & $\begin{array}{l}\text { Profitability } \\
\mathbf{R}^{\mathbf{2}}=\mathbf{0 . 8 3 7}\end{array}$ & & \\
\hline Strategy & $\begin{array}{l}0.323 * * * \\
(\mathrm{t}=3.036)\end{array}$ & $\begin{array}{c}0.083 \mathrm{~ns} \\
(\mathrm{t}=0.873)\end{array}$ & & $\begin{array}{c}0.777 * * * \\
(\mathrm{t}=16.383)\end{array}$ \\
\hline Firm assets & $\begin{array}{l}0.546 * * * \\
(\mathrm{t}=6.625)\end{array}$ & $\begin{array}{c}-0.055 \\
(\mathrm{t}=0.114)\end{array}$ & $\begin{array}{l}0.617 * * * \\
(\mathrm{t}=9.835)\end{array}$ & \\
\hline $\begin{array}{c}\text { Industry Forces } \\
\text { Competitive rivalry } \\
\text { Barries to entry } \\
\text { Threat of substitutes } \\
\text { bargaining power of buyers, } \\
\text { bargaining power of suppliers }\end{array}$ & $\begin{array}{c}-0.039 \\
(\mathrm{t}=0.322) \\
0.084 \mathrm{~ns} \\
0.001 \mathrm{Ns} \\
0.106 \mathrm{Ns} \\
-0.046 \mathrm{~ns}\end{array}$ & $\begin{array}{l}0.111 * \\
(\mathrm{t}=1.99) \\
0.014 \mathrm{~ns} \\
0.118 \mathrm{~ns} \\
-0.112 \mathrm{~ns} \\
-0.124 * *\end{array}$ & & \\
\hline Market performance & $\begin{array}{c}- \\
0.125^{* *} \\
(\mathrm{t}=1.907)\end{array}$ & $\begin{array}{c}0.824 * * * \\
(\mathrm{t}=12.673) \\
0.107 * * * \\
(\mathrm{t}=11.642)\end{array}$ & & \\
\hline
\end{tabular}

Two-tail test*** denotes $\mathrm{p}<0.01 ; * * \mathrm{p}<0.05$ : t-statistics in absolute value.

Hypothesis on mediating effect has been tested following Preacher and Hayer approach $(2004,2008,2011)$ and shown in Table 2.

Table 5: Mediating Effects on Firm Performance (Market performance and profitability).

\begin{tabular}{|c|c|c|}
\hline & $\begin{array}{c}\text { Indirect } \\
\text { effect }\end{array}$ & $\begin{array}{l}\text { Confidence } \\
\text { Interval }\end{array}$ \\
\hline Firm assets $\rightarrow$ Strategy $\rightarrow$ Market Performance & $\begin{array}{c}0.1992 \\
(\mathrm{t}=2.90)\end{array}$ & $(0.0645,0.3345)$ \\
\hline $\begin{array}{c}\text { Firm assets } \rightarrow \text { Strategy } \rightarrow \text { Profitability } \\
\text { Firm assets } \rightarrow \text { Strategy } \rightarrow \text { Market Perf } \rightarrow \text { profitability }\end{array}$ & $\begin{array}{l}0.2154 \\
(t=2.87)\end{array}$ & $(0.0739,0.3654)$ \\
\hline Strategy $\rightarrow$ Competitive Rivalry $\rightarrow$ Market Performance & $\begin{array}{l}-0.030 \mathrm{~ns} \\
(\mathrm{t}=0.34)\end{array}$ & $(-0.2172,0.1485)$ \\
\hline $\begin{array}{c}\text { Strategy } \rightarrow \text { Competitive Rivalry } \rightarrow \text { Profitability } \\
\text { Strategy } \rightarrow \text { Competitive Rivalry } \rightarrow \text { Market } \\
\text { performance } \rightarrow \text { Profitability }\end{array}$ & $\begin{array}{c}0.061 \\
(t=0.45)\end{array}$ & $(-0.153,0.098)$ \\
\hline Competitive Rivalry $\rightarrow$ Market Performance $\rightarrow$ Profitability & $\begin{array}{c}-0.0321 \\
(\mathrm{t}=-0.33)\end{array}$ & $(-0.2243,0.1601)$ \\
\hline
\end{tabular}

Two-tailed test ${ }^{* * *}$ denotes $\mathrm{p}<0.01 ; * * \mathrm{p}<0.05$ : t-statistics in absolute value.

Firm assets appear to have a significant positive direct effect on Market performance, and also an indirect effect through strategy is observed. Strategies also have a positive direct effect on firm performance but do not have an indirect effect on market performance. Neither 
direct nor indirect effect of strategies on profitability is observed.

According to results achieved from the direct and indirect effect of the variables, firm assets, strategy and industry forces: $\mathrm{H} 1$ is fully confirmed. $\mathrm{H} 2$ is partially confirmed only direct effect on profitability is observed. H3 is partially confirmed since strategies have a direct effect on Market performance

The standardized root mean square residuals (SRMR) defined as the difference between the observed correlation and the predicted correlation is considered a goodness of fit measure for PLS-SEM to detect model misspecification (Henseler et al., 2014). A value less than 0.10 and of 0.08(more conservative) (Hu and Bentler, 1999) is considered a good fit. For our composite factor model SRMR takes value 0.10 revealing the model specification can be improved.

\section{Conclusions}

The study is an attempt to reveal the mechanism through which industry and firm assets influence performance. Results seem to support arguments drawn from manufacturing sector literature that consider both industry (Rivalry) and firm-level influences (Firm Strategy and Firm asset) are significant determinants of performance. Furthermore, our findings seem to suggest that: 1) industry forces (Rivalry) do not influence market performance and profitability through market performance; 2) Firm assets influence market performance and via the market performance (indirect effect) influence profitability. 3) When measuring industry forces by single items representing Power of suppliers/buyers, barriers to entry and threat of substitutes, only barriers of entry has a direct and negative effect on performance.

\section{References}

Amit, R., \& Schoemaker, P.J. (1993).Strategic assets and organizational rent, Strategic Management Journal, 14, pp.33-46.

Aranda Hipólito, A. W. (1994). Gestión Técnico-Económica de Hoteles. Madrid: Centro de Estudios Ramón Areces.

Barney, J. B. (1986). Strategic factor markets: Expectations, luck and business strategy. Management Science, 32 (4), pp. 1231-1241.

Barney, J. B. (1991). Firm resources and sustained competitive advantage, Journal of Management, 17 (1), pp. 99-120.

Barney, J. B. (1999). How a firm's capabilities affect boundary decisions. Sloan Management Review, vol. 40, n⿳3, pp.137-145.

Bonzemba, E. L., \& Okano, H. (1998). The Effects of Target Costing Implementation on an Organizational Culture in France. Second Asian Interdisciplinary Research in Accounting Conference, Osaka City University, Japón.

Bote Gómez, V. (1993). La necesaria revalorización de la actividad turística española en una economía terciarizada e integrada en la CEE. Estudios turísticos $\mathrm{n}^{\mathrm{o}}$ 118, pp. 5-26, Instituto de Estudios Turísticos. Madrid.

Bueno Campos, E. (1993). Curso básico de economía de la empresa: un enfoque de organización. Madrid: Pirámide.

Bueno Campos, E. (1996). Organización de empresas: estructura, procesos y modelos. Madrid: Pirámide. 
Camisón, J. C. (1997). La competitidad de la PYME industrial española: estrategia y competencias distintivas. Generalitat Valenciana:Editorial Civitas.

Casanueva, C., García, J., \& Caro, F.J. (2000). Organización y gestión de empresas turísticas. Madrid: Pirámide.

Cerra, A. J., Dorado, J. A., Estepa, D., \& García, P.E. (1997). Gestión de Producción de Alojamientos y Restauración. Madrid: Síntesis.

Coltman, M. M. (1992). Financial Control for your Hotel. New York: Van Nostrand Reinhold, Cap. 9.

Cuervo García, A. (2004). Dinámica empresarial y consolidación sectorial. Universia Business Review, Nº1, pp. 96-105.

Dijstra, T.K. and Henseler, J. (2015). Consistent Partial Least Squares Path Modeling. MIS Quarterly, v. 39, no. X, pp. 1-XX.

Dorado, J. A. (1996). Organización y Control de Empresas de Hostelería y Turismo. Madrid: Síntesis.

Espino T. F., \& Padrón, V. (2005): El valor estratégico y la externalización de actividades: un análisis desde la perspectiva de recursos y capacidades. Cuadernos de Economía y Dirección de la Empresa, núm. 23, pp.61-92

Exceltur (2007). Impactur Andalucía 2005: Estudio del impacto económico del Turismo. http://exceltur.org/excel01/contenido/portal/

Fernández, Z. (1993). La organización interna como ventaja competitiva para la empresa. Papeles de Economía Española, 56, págs.178-193.

Figuerola Palomo, M. (1991). Elementos para el estudio de la economía de la empresa. Madrid: Centro de Estudios Ramón Areces.

Figuerola Palomo, M. (1995). Economía para la Gestión de las Empresas Turísticas (Producción y Comercialización). Madrid: Centro de Estudios Ramón Areces.

Giannakis, M. (2001). Supply Chain Management and the Role of Inter-Organisational Relationships in Service Organisations. 12th Annual Conference of the Production and Operations Management Society, Orlando. Retrieved from http://www.poms.org/POMSWebsite/Meeting2001/2001/cd/_papers pdf/Giannakis.pdf.

Grant, R. M. (1991). The resource- based theory of competitive advantage: implications for Strategy formulation, California Management Review, 33 (2), pp. 114-135.

Grant, R. M. (1992). Contemporary strategy analysis: Concepts, techniques, applications. Cambridge, MA, Estados Unidos: Basil Blackwell. [Translation made by Férnández Z., Lorenzo G., Ruiz, J. en Grant (1995). Dirección Estratégica: conceptos, técnicas y aplicaciones. Editorial Civitas].

Grant, R. M. (1996): Dirección estratégica. Conceptos, técnicas y aplicaciones. Madrid:Civitas.

Hair, J.F., Hult, G.T., Ringle, C.M., Sarstedt, M. (2014). A primer on partial least squares structural equation modelling (PLS-SEM). London: Sage.

Henseler, J., Ringle, C.M., and Sinkovics, R.R. (2009). The use of partial least squares path modelling in international marketing. Advances in International Marketing, 20, pp.277-320.

Henseler, J., Dijkstra, T. K., Sarstedt, M., Ringle, C. M., Diamantopoulos, A., Straub, D. W., Ketchen, D. J., Hair, J. F., Hult, G. T. M., and Calantone, R. J. (2014). Common Beliefs and Reality about Partial Least Squares: Comments on Rönkkö \& Evermann (2013), Organizational Research Methods 17(2): 182-209.

Henseler, J. Ringle, C.M, and Sarstedt, M. 2015. A New Criterion for Assesing Discriminant Validity in Variance-based Structural Equation Modelling. Journal of the Academy of Marketing Science, 43(1), pp. 115-135. 
Horwath Consulting España (1999). La Industria Hotelera Española. Barcelona: Horwath Consulting España.

Hotel Association Of New York City (1996). Uniform System of Accounts for the Lodging Industry, $9^{\text {a }}$ ed. Michigan, USA: Educational Institute of the American Hotel \& Motel Association.

Hu, L.-t., and Bentler, P. M. 1998. Fit Indices in Covariance Structure Modeling: Sensitivity to Underparameterized Model Misspecification, Psychological Methods 3(4): 424453.

INE (2011). Cuenta satélite del turismo de España. Base 2000. Retrieved from http://www.ine.es.

Lastres, J.A., Rivero,Mª.J., \& Moreno, R.C. (2003). Las Capacidades Estratégicas más frecuentes en la industria hotelera Mexicana. I Congreso Internacional y Virtual de Intangibles.

Retrieved

from http://fama2.us.es:8080/turismo/turismonet1/economia\%20del\%20turismo/hosteleria/c apacidades $\% 20$ estrategicas $\% 20$ industria $\% 20$ hotelera\%20mexicana.pdf.

Mahoney, J. (1995). The management of resources and the resource of management. Journal of business research, vol.33, pp. 91-101.

Mahoney, J., \& Pandian, R. (1992). The resource-based view within the conversation of strategic management. Strategic Management Journal, Vol. 13, pp.363-380.

Mallo, C., \& Merlo, J. (1996). Control de Gestión y Control Presupuestario. Madrid: McGraw-Hill.

Martín Rojo, I. (2000). Dirección y gestión de empresas del sector turístico. Madrid: Pirámide.

Mazars Turismo (2000). La Industria Hotelera Española. Barcelona: Mazars Turismo.

Mills, P.K., Chase, R.B., \& Margulies, N. (1983). Motivating the client/employee system as a service production strategy. Academy of management Review, ${ }^{\circ}$ 8, pp.301 310.

Monfort, V. (2000). Recursos y Capacidades de la hostelería de litoral: Benidorm y Peníscola. Estudios turísticos, núm. 143, pp. 25-63.

Oller Nogués, J. (1997). La creación y mejora de empresas turísticas. Bilbao: Deusto.

Olsen, M., West, J., \& Ching -Yick Tse, E. (1992). Strategic Management in the Hospitality Industry. New York: Van Nostrand Reinhold.

Penrose, E. (1959). The theory of the growth of the firm. New York:John Wiley and Sons, pp. 173-147.

Porter, M. E. (1980). Competitive strategy. Nueva York: The Free Press.

Porter, M. E. (1985). Competitive advantage. Nueva York:The Free Press.

Ringle, C.M., Wende, S., \& Will, A. (2005). SmartPLs 2.0 [Computer software]. Retrieved from http://www.smartpls.de.

Ringle, C., Sarstedt, M. \& Straub, D.W. (2012). A critical look at the use of PLS-SEM. Mis Qarterly, 36, pp.3-14.

Ripoll, V., \& Balada, T. J. (1992). La reducción de costes mediante la actualización de los sistemas de control: el caso de Ford España. Jornada sobre la Contabilidad de gestión en el actual contexto empresarial: Nuevas Tendencias y Procedimientos, diciembre, Madrid.

Sánchez Mateos, I. (1999). Adaptación del "Uniform System” a los Hoteles en España. Madrid: Editorial Puzzle.

Sasser, W.R., Olsen, R.P., \& Wyckoff, D.D. (1978). Management of service operations: Text, cases and readings. Boston:Allyn and Bacon. 